$12-17-2015$

\title{
Development and Dissemination: Deliberations on Spanish Renaissance Music
}

Lindsey E. Pfeifer

Cedarville University, lepfeifer@cedarville.edu

Follow this and additional works at: https://digitalcommons.cedarville.edu/musicalofferings

Part of the Ethnomusicology Commons, Fine Arts Commons, Musicology Commons, Music Performance Commons, and the Music Theory Commons

DigitalCommons@Cedarville provides a publication platform for fully open access journals, which means that all articles are available on the Internet to all users immediately upon publication. However, the opinions and sentiments expressed by the authors of articles published in our journals do not necessarily indicate the endorsement or reflect the views of DigitalCommons@Cedarville, the Centennial Library, or Cedarville University and its employees. The authors are solely responsible for the content of their work. Please address questions to dc@cedarville.edu.

\section{Recommended Citation}

Pfeifer, Lindsey E. (2015) "Development and Dissemination: Deliberations on Spanish Renaissance Music," Musical Offerings: Vol. 6 : No. 2 , Article 1.

DOI: 10.15385/jmo.2015.6.2.1

Available at: https://digitalcommons.cedarville.edu/musicalofferings/vol6/iss2/1 


\title{
Development and Dissemination: Deliberations on Spanish Renaissance Music
}

\section{Document Type}

Article

\begin{abstract}
Every musical culture grows and developed under a specific set of influences, whether political, philosophical, or geographical. Varying sets of influences create likewise varying types of music. Spanish music, in particular, enjoyed an especially unique array of influences during the fifteenth century. My presentation explores these influences. How did the interaction of Spain's three major religions-Christianity, Islam, and Judaism-affect musical development? How did the newly unified government, ruled by Ferdinand II of Aragon and Isabella I of Castile, influence the musical culture? How did Spain's discovery and conquest of the New World facilitate the spread of Spanish music beyond its borders?
\end{abstract}

These three factors made Spain distinct from other Western nations during the fifteenth century. In my presentation, I first describe the interaction of Christianity, Islam, and Judaism. This synergy created a rich, collaborative community of shared musical ideas, prompting the development of both sacred and secular genres. Next, I address the influence that Spain's unified government exerted on the musical culture. Historically, politics have played a substantial role in the development of music. Spain is distinctive in this respect because most other nations during this time were not unified under one ruler, whereas Spain was. This unique governmental structure in turn affected the musical culture. Lastly, I will explain how the spread of Spanish music and its interaction with native tribes in America impacted its development, both within and outside Spain's borders. Spain was particularly poised to both exert their influence and be influenced by the different people groups they encountered in the New World. These three factors would create a uniquely Spanish music culture.

\section{Keywords}

Cristobal de Morales, Spain, Renaissance, sacred music, flamenco, New World, Christianity, Judaism, Islam, interaction of music cultures, Mozarabic rite, muwashshah, Spanish Inquisition, Native Americans

\section{Creative Commons License}

\section{(c) (i) $\ominus$}

This work is licensed under a Creative Commons Attribution-Noncommercial-No Derivative Works 4.0 License. 


\title{
Development and Dissemination: Deliberations on Spanish Renaissance Music
}

\author{
Lindsey Pfeifer \\ Cedarville University
}

$\mathrm{M}$ usical development and dissemination is limited only by the culture in which it is found. Cultures that possess a rich diversity of people and cultural events will likewise possess an enriched musical culture. Renaissance Spain is a perfect example of this. During the Renaissance, Spain was unique from many other contemporary nations. From the fifth century through the end of the fifteenth century, three major religious groups found their home in the Iberian Peninsula. The interaction between Christianity, Islam, and Judaism created a diverse and distinctive musical environment. This interaction was sometimes friendly and sometimes antagonistic, and both atmospheres affected the musical culture, creating the sounds of flamenco music as well as influencing sacred music. Politically, Spain was in a unique position at the closing of the fifteenth century and the beginning of the sixteenth with the marriage of Ferdinand II of Aragon and Isabella I of Castile. Their marriage signaled the unification of Aragon and Castile, creating the nation of Spain. Other Western countries at this time, such as Italy and France, remained a collection of dukedoms and somewhat independent states. Such an unusual system of government would create a likewise uncommon culture of music in Spain. Reaching past political boundaries, Spain's involvement in the New World facilitated the spread of Spain's unique musical culture beyond its own borders. Ferdinand and Isabella's sponsorship of Christopher Columbus' historic quest led to centuries of Spanish involvement in the conquest of the New World. While much of the cultural exchange involved the passing of Spanish customs and values, the natives of the New World also passed some of their own traditions on to the conquistadors. Both types of interaction are worthy of consideration. These three items considered, Renaissance Spain offered a unique environment for the development and dissemination of its musical culture.

Musical Offerings, vol. 6, no. 2, pp. 61-72. ISSN 2330-8206 (print); ISSN 2167-3799 (online);

(C) 2015, Lindsey Pfeifer, licensed under CC BY-NC-ND (http://creativecommons.org/licenses/by-nc-nd/3.0/) 
Often, the richest cultures are actually a mixing of several cultures. Spain is a great example of this. Prior to the Renaissance, Christians, Muslims, and Jews occupied Spain. These three religions and cultural units created a rich diversity of culture in Spain, not only in daily life and beliefs, but also in musical practices. Although there was certainly conflict - sometimes very intense conflict—between these groups, they created a distinct "Spanish" culture.

The cohabitation of any combination of cultures is always a delicate balance between peaceful coexistence and tense disagreement. This is certainly true of Spain during the Renaissance. The Muslims arrived in Spain in the early eighth century. ${ }^{1}$ There is some dispute about whether Muslims coexisted peacefully with Christians and Jews already living in Spain. Some say that the groups struggled bitterly until many Muslims and Jews migrated as a result of the Spanish Inquisition. Others say that the mixing of cultures was peaceful, since the Muslims offered religious freedom to the cities that they conquered. Jonathan Shannon describes the time of peace between Jews, Christians and Muslims as the convivencia, or "the living together." According to Shannon, during this convivencia, Muslim culture thrived, rivaling Baghdad, the Islamic cultural center. ${ }^{2}$ Unfortunately, conflict did exist between the three religious groups during this time as well. The years in between the arrival of the Moors in AD 700 and their mass exodus in 1492 were also filled with conquering and reconquering different Christian or Muslim cities, each interaction creating another opportunity for the exchange of culture.

The Muslim's main influence on Spanish musical development was the creation of flamenco music. This genre has strong ties to Greek music theory, which was introduced to Spain by the Muslims. In his article about the Greek origins of Flamenco music, Manolo Sanlucar claims that Spanish Muslims are considered the most direct link to the spread of Hellenistic culture throughout Spain. ${ }^{3}$ Jonathan Shannon agrees that Flamenco music is a direct result of the development of Arab music in

\footnotetext{
${ }^{1}$ Américo Castro, The Structure of Spanish History (Princeton, NJ: Princeton, 1954), 84.

${ }^{2}$ Jonathan H. Shannon, "Performing al-Andalus, Remembering al-Andalus: Mediterranean Soundings from Mashriq to Maghrib," Journal of American Folklore 120 (2007): 312. doi:10.1353/jaf.2007.0060.

${ }^{3}$ Manolo Sanlucar and Corey Whitehead, "The Speculative Theories of Manolo Sanlucar: The Greek Origins of Flamenco Music," International Journal of the Humanities 7 (2011): 7.
} 
the Muslim-populated areas of Spain. ${ }^{4}$ While most people attribute the development of flamenco music to Flemish culture, there are records of it existing in Spain long before the Flemish records of 1550. In addition, these records predate the development of the tonal system in the Western world, again pointing to origins besides those of the Western world. ${ }^{5}$ The Greeks used what is known as the "overtone series," which is the theory that a single pitch suggests or produces a number of notes around it. Overtones are prevalent in the singing of flamenco music. In his research, Sanlucar discovered an obvious connection between the Greek Greater Perfect System and the "tonal pallet" of Flamenco music. ${ }^{6}$ In the Greater Perfect System, Greek musicians utilized four main modes: Dorian, which begins on "E;" Phrygian, which begins on " $\mathrm{D}$;" Lydian, which begins on "C;" and Mixolydian, which begins on "B." Rearranging the succession of tones and semitones, or whole steps and half steps, respectively, creates these different scales. From these building blocks, musicians can create different inversions of each mode, creating even more structural options for compositions. ${ }^{7}$ A typical mode used by flamenco musicians was the Dorian mode, which begins on "E." This mode is created by two identical, descending tetrachords, with the pattern "Tone, Tone, Semitone," or "T, T, S." By juxtaposing these matching tetrachords, separated by a tone, the pattern becomes, "T, T, S, T, T, T, S." ${ }^{8}$ This unique pattern of tones and semitones creates the distinct sound of flamenco music. Greek modes and music theory played a huge part in the development of Flamenco music in Spain - a genre still popular today. The Muslim people, who had close ties with Greek culture, brought these musical ideas when they immigrated to Spain, diversifying the musical culture of Spain.

Two other musical practices with Spanish Muslim roots are the muwashshah and the Mozarabic rite. The muwashshah was a body of poetic texts set to modal music that were developed in Spain during the tenth century in Cordoba and Granada. ${ }^{9}$ Its poetry refers to the Muslim history in Spain, indicating that the Muslims considered their time in Spain their golden era. The Mozarabic rite was a Muslim-influenced Catholic rite, developed in the $7^{\text {th }}$ and $9^{\text {th }}$ centuries. It was allowed to coexist with the Roman rite, but it ultimately ceased when the Muslims

\footnotetext{
4 “Performing al-Andalus," 317.

5 "Greek Origins of Flamenco Music," 7.

${ }^{6}$ Ibid., 9.

${ }^{7}$ Ibid., 10-11.

${ }^{8}$ Ibid.

9 “Performing al-Andalus," 316.
} 
left Spain. ${ }^{10}$ The Mozarabic rite, similar to flamenco music, differed from the Roman rite in its use of overtones and tone inflections that are different than the tones and melodies used in traditional Gregorian chant. These unique tones point to this rite's Arabic roots. The Muslim influence on Spanish musical development is undeniable, as seen in the development of flamenco, muwashshah, and the Mozarabic rite.

The Christian influence on Spanish music, especially sacred music, is perhaps most recognizable, since Catholicism became the official religion when Ferdinand and Isabella united the Spanish throne in 1464. Spain's sacred music was primarily influenced by Rome and the Catholic Church, in order to avoid too much influence from nonChristian Spaniards. Although Spanish sacred music had much in common with other Western sacred music, composers such as Cristóbal de Morales wrote music that helped to distinguish it from other sacred music during the Renaissance.

The works of Cristóbal de Morales are an excellent representative of Spanish sacred music during the Renaissance. He was one of the most well known Renaissance musicians, both during his lifetime and for two centuries after his death. In fact, Morales was often categorized with Josquin des Prez, one of the most studied and honored sacred music composers in history. Isabel Pope explains that Spanish music at this time was uniquely simple and straightforward, compared to other traditions that included many complex, contrapuntal writings. Morales composed within the goal of Spanish composers at the time, which was to support the text, rather than hinder it, by writing simple music. ${ }^{11}$ An example of this in Morales' own compositions is his Offices for Four Voices. Much of this composition is set homo-rhythmically between the voices, making the text even more clear. The presto sections set the voices more independently, yet Morales still makes the text come through clearly. ${ }^{12}$ Morales' simple way of writing influenced on of his more famous contemporaries, Palestrina. Robert Stevenson argues that it was Morales's compositions and handling of counterpoint in a text setting that influenced Palestrina as he composed his Pope Marcellus Mass, the mass that convinced Pope Marcellus to allow polyphony to

${ }^{10}$ Sandra Yang, "Strengthening the 'History' in 'Music History': An Argument for Broadening the Cross-disciplinary Base in Musicological Studies," College Music Symposium 49 (2009): 241.

${ }^{11}$ Isabel Pope, "Spanish Secular Vocal Music of the Sixteenth Century," Renaissance News 2 (1949): 3, doi:10.2307/2857475.

12 Cristóbal De Morales, ed. Felipe Pedrell, "Officium Defuntorum," Hispaniea Schola Musica Sacra, Vol. 1 (1894). 
remain a part of Catholic sacred music. ${ }^{13}$ Morales' influence can be seen in Palestrina's text setting. In the Gloria, Palestrina writes the voices singing the same text at the same time, so as not to confuse the words that are being said, accentuating their meaning. In the less verbose Kyrie, Palestrina pushes the limits of clear text expression, but even when he sets the voices very independently, he tends to write entrances of a voice during a melisma of other voices, allowing the text to still come across clearly. ${ }^{14}$ Morales certainly had an important impact on sacred music in other western countries, as well as nations outside of Europe. In fact, some of his masses became quite popular in the New World, specifically Mexico and Peru. His book of masses was very much admired in the Incan capital in 1544. Morales' distinctively "Spanish" style of writing allowed him to be successful both in Spain and in other countries.

In addition to clear and simple compositions, Morales utilized other Spanish-inspired techniques in his writing. During his career, Morales spent ten years in Rome, composing and performing in the service of the pope. While there, he composed Jubilate Deo omnis terra for a conference in 1538. A distinctive feature of this six-voice motet is a six-note melodic ostinato that repeats throughout the composition. While Morales did not invent this idea, it was very prevalent in Spanish music at the time.$^{15}$ Another distinctive aspect of Morales' music is his experimentation with different rhythmic meters. This practice is widely known today, but during the Renaissance this was quite rare. Again, Morales did not originate this practice, but his works show significantly more interest and development of this practice than his contemporaries. ${ }^{16}$ Overall, Morales shows a great deal of thoughtfulness towards the use of dissonance and voice leading, as well as his creation of harmonic progressions and text setting. Morales' amalgamation of sacred church music and Spanish elements added another dimension to the development and dissemination of Spanish music.

Because of their nomadic history, the Jewish people have absorbed many features of other cultures. This is definitely seen in their musical practices, particularly those developed in Spain. A large population of Jews moved to Spain around AD 400. They coexisted with Christians

\footnotetext{
${ }^{13}$ Robert Stevenson, Spanish Cathedral Music in the Golden Age (1961), 6.

14 Palestrina, ed. Otto Goldschmidt, "Missa Papae Marcelli," Novellos Original $8^{\text {th }}$ edition (n.d.).

${ }^{15}$ Spanish Cathedral Music in the Golden Age, 19.

16 Ibid., 50.
} 
and Muslims for several centuries, contributing to the unique melting pot of Spanish musical culture. Like the Muslims, many Jews left Spain around 1492 as a result of the Spanish Inquisition. While in Spain, they were exposed to Christian and Muslim poetry and adopted many of their respective musical and poetic practices. In recognition of the destruction of their temple in $\mathrm{AD} 70$, the leaders of the Jewish community restricted Jewish participation in music outside of liturgical worship. As a result, there are no secular Jewish genres that can be traced back to Spanish origins. ${ }^{17}$ However, Jewish participation in musical activities proved to be invaluable. Their knowledge of Arabic proved helpful in translating various musical treatises, which were then studied by Christian and Muslim musicians. ${ }^{18}$ Jews also participated in musical performances, and were an important element in the spread of other Spanish musical traditions. One Muslim musical tradition that became popular in Jewish culture was the zajal, which was very similar to the muwashshah. Both were originally written in Arabic, although the Jews composed theirs in Hebrew, and called them "love lyrics."19 These "love lyrics" usually contained five strophes; however the structure of this repertoire was not very strict. They were expressions of desire for the beloved, from the point of view of both men and women. Although this secular genre originated in Islamic culture, it was used and adapted into Jewish musical tradition due to the mixing of cultures.

Regarding their sacred musical traditions, the Jews brought their psalms and prayers of Babylonian origin with them when they settled in Spain. Because Spanish Jews did not have a single, unified liturgy, each individual community created its own liturgy for worship. Eventually, their leaders compiled the Siddur amram, which was a collection of prayers for the liturgical year. This became quite popular throughout Spain and eventually in other countries as well. ${ }^{20}$ Because of the collaboration of Jewish leaders, Spanish Jews were able to have a lasting impact on Jewish sacred music, both within and outside of Spain. Likewise, the Jewish collaboration with Muslims and Christians also widened their repertory and allowed them to have a lasting impact on Spanish musical practice.

\footnotetext{
${ }^{17}$ Carol E. Robertson, ed., Musical Repercussions of 1492: Encounters in Text and Performance (Washington D.C.: Smithsonian Institution Press, 1992), 103.

${ }^{18}$ Ibid., 104.

${ }^{19}$ Jean Dangler, "Subject Crossings in Andalusi Lyric," Revista de Estudios Hispanicos 38 (2004): 303.

${ }^{20}$ Musical Repercussions of 1492, 103.
} 
Spain's political system also distinguished it from other Western nations during the Renaissance. When Ferdinand and Isabella were married, their respective kingdoms of Aragon and Castile became one as well. This gave them an advantage over the other, less organized nations of Europe and motivated them to assert their authority and expand their kingdom even further. Besides sponsoring the voyage that discovered the New World, the most significant event that marked the reign of Ferdinand and Isabella was the Spanish Inquisition. This attempt to purify their Catholic nation served to alienate the other two religious groups that resided in Spain: Jews and Muslims. This was in striking contrast to the centuries of coexistence and tolerance between Jews, Muslims, and Christians. Certainly there had been conflicts between the three groups during their shared history in the Iberian Peninsula, but the methodical rejection of the Jewish and Muslim faiths was a drastic measure. The absence of two once-thriving people groups from Spain certainly affected the culture of Spain at the turn of the century, including its musical practices.

The idea of an inquisition originated in the first century in Roman law, but was eventually adopted by Christians as they gained public and political recognition. ${ }^{21}$ Inquisitions had been occurring for centuries throughout Spain in an attempt to purify the culture from heretics and those who did not agree with the Catholic Church, but they came to a head under the reign of Ferdinand and Isabella. This zeal for religion was partly in response to the previous reign of Henry IV of Castile, who, in their opinion, had failed to promote the Catholic Church in his kingdom, becoming lax in his policies against the Jews and other "heretics." ${ }^{22}$ Thus, Ferdinand and Isabella enacted an aggressive program against those they saw as opposing the Catholic ChurchJews especially, but also Muslims. In 1478, they requested a papal bull to institute an inquisition of all those they saw as threats to Catholicism. Pope Sixtus IV granted this request, and by 1480 the Spanish Inquisition had begun. ${ }^{23}$ For the next twelve years, the Jewish and Muslim faiths were squelched, drastically reducing the number of Jews and Muslims who remained in Spain.

The Spanish Inquisition was an attempt by the monarchs to strengthen their association with the Catholic Church. In fact, these events earned Ferdinand and Isabella the nickname "The Catholic Monarchs." Henceforth, it was not uncommon to refer to Ferdinand as "Ferdinand

\footnotetext{
${ }^{21}$ Edward Peters, Inquisition (New York: Free Press, 1988), 11.

${ }^{22}$ Ibid., 84.

${ }^{23}$ Ibid., 85.
} 
the Catholic" and Isabella as "Isabella the Catholic." This increased association with the church was partly achieved by simply building more Catholic places of worship in Spain. The wealth that Spain was gleaning from the New World made this possible, giving the monarchs more money to invest in the development of churches within their kingdom. ${ }^{24}$ As seen in the career of Morales, the Catholic Church considered music an integral part of their worship services, so naturally, the increase in the number of cathedrals would coincide with an increase in the number of people involved in musical practices. Perhaps even more obviously, the unification of Spain and the presence of fewer Jews and Muslims meant a significant decrease in those musical practices associated with those respective people groups. While their traces can still be seen in Spanish music, practices such as Jewish liturgy and Muslim-influenced Mozarabic rites mostly ceased when the cultures likewise ceased to exist within Spain. Clearly, the unification of Spain under King Ferdinand and Queen Isabella drastically changed Spanish culture, including its musical culture.

Besides having a musical culture developed by the interaction of three different religions and the later development of a unified government, Spain had the unique opportunity of spreading its culture through its colonization of the New World, beginning with Christopher Columbus in 1492. When Columbus first discovered a landmass previously unknown to the Western world, nations rushed to claim their share of the riches and land of this New World. Some nations achieved this goal, particularly Spain and England, and they ended up claiming different aspects of the native cultures, as well as inserting their own culture into the existing native culture.

One important way that culture was exchanged was through the establishment of missions throughout the New World. This allowed the Spaniards to project their own culture and beliefs upon the native tribes that they encountered. These missions not only spread the Catholic faith to the native peoples, but also shared their sacred music tradition. The Catholic group that was most involved in spreading the musical culture was the Franciscans. ${ }^{25}$ The first Franciscan bishop of Mexico City, Juan de Zumárraga, commented that music was an excellent way to convert the natives to the Catholic faith, because the natives already possessed a rich, musical culture, so they were open to hearing new musical ideas. ${ }^{26}$ Spaniards also brought their Western instruments to the

\footnotetext{
${ }^{24}$ Spanish Cathedral Music in the Golden Age, 11.

${ }^{25}$ Musical Repercussions of 1492, 172.

${ }^{26}$ Ibid., 173.
} 
New World, including stringed instruments, which were originally introduced into Spanish culture by the Arabs. ${ }^{27}$ Stringed instruments, in particular the guitar, remain important instruments in Hispanic and other American cultures today.

Not only did the conquistadors bring instruments and genres to the New World, they also discovered musical genres alive and active prior to their discovery of the foreign cultures. Native Americas had developed a complicated flute system that they believed enabled them to communicate with their ancestors and the deities that they worshipped. ${ }^{28}$ This was done through the performance of certain tonal and rhythmic patterns that were highly connected to their religious beliefs. The minor third provided the basis for much of this music. ${ }^{29}$ This discovery of a thriving musical practice outside of the Western nations served to broaden the Spanish repertory of musical practices, by exposing them to different instruments and tonal practices.

A curious interaction between Western and Native American culture was dance. Both cultures possessed a highly developed form of dance that was an important part of their society, and both used dance in different religious rituals and festivals throughout the year. However, the Catholic priests, especially those belonging to the Franciscan order, were very concerned by the sensuality they saw in the Native American dances. ${ }^{30}$ This partly stemmed from what John Haines calls the "European superiority complex," which caused Europeans to view different Native American traditions as heathen and savage-like. ${ }^{31}$ Despite the concern of the Franciscan priests, Europeans, Spaniards included, were also fascinated with the dancing of Native Americans. They would often import American performers, much like they imported slaves, and force them to perform in their courts as entertainment, advertising the wealth they were gaining in their conquest of the New World. While this interaction with Native American dance was not altogether positive, it was nonetheless an element of the development of Spanish music at this time. It can certainly be argued that colonizing nations, Spain in particular, entered

\footnotetext{
${ }^{27}$ Anne Rasmussen, “The Arab World." In Worlds of Music: An Introduction to the Music of the World's Peoples, ed. Jeff Todd Titon (2009): 503.

${ }^{28}$ Musical Repercussions of 1492, 35.

${ }^{29}$ Ibid., 69.

30 John Haines, "The Earliest European Responses to Dancing in the Americas," U.S. Catholic Historian 30, no. 4 (2012) 1-20.

doi: $10.1353 / \mathrm{cht} .2012 .0021$.

${ }^{31}$ Ibid., 5 .
} 
the New World with the goal of converting native tribes to their own culture, but the outcome would not as simple as that. Spanish explorers and Native Americans interacted in a complex exchange of culture, in which both groups adopted musical practices that were learned from the opposite group.

It is clear that the development and dissemination of Spanish music was very different than that of other Western nations during the Renaissance. This was due in part to the interaction of Christian, Jewish and Muslim peoples in Spain prior to the Spanish Inquisition. The diverse collaboration allowed for the exchange of musical ideas and practices, creating new genres such as flamenco and muwashshah, as well as the works of Cristóbal de Morales. In addition, Spain possessed a unified government, contrasting the loose associations and dukedoms of other nations at the time. The unified government influenced the music that was developed in Spain especially after the Catholic monarchs expelled the Jews and Muslims from the country. Thanks to Christopher Columbus, and the sponsorship of the Catholic Monarchs, Spain was able to have a unique way of spreading its musical culture through its discovery of the New World. As a result, Spanish music can be seen in the Americas, and elements of Native American music can be seen in Spanish music. Ultimately, the study of Spanish music reveals that its development was a series of idea exchanges from one people group to another, whether these people were in Europe or the newly discovered Americas. This fascinating exchange allowed Spain to develop a uniquely "Spanish" musical culture, distinguishing it from other nations during the Renaissance. 


\section{Bibliography}

Castro, Américo. The Structure of Spanish History. Translated by Edmund L. King. Princeton, NJ: Princeton University Press, 1954.

Dangler, Jean. "Subject Crossings in Andalusi Lyric." Revista de Estudios Hispanicos 38 (2004): 303-316. Accessed November 3, 2014.

Fernandez-Armesto, Felipe. Ferdinand and Isabella. New York: Taplinger Publishing Company, 1975.

Haines, John. "The Earliest European Responses to Dancing in the Americas." U.S. Catholic Historian 30, no. 4 (2012): 1-20. doi: 10.1353/cht.2012.0021.

Jacobson, Joshua R. "Music of the Jewish People." Choral Journal 55, no. 2 (2014): 67-69.

Lowney, Chris. A Vanished World: Medieval Spain's Golden Age of Enlightenment. New York: Free Press, 2005.

Morales, Cristóbal De. Magnificat. Stephen Rice. Recorded September 2007. Hyperion CDA67694, 2008, compact disc. . "Officium Defuntorum," Hispaniea Schola Musica Sacra, Vol. 1. Edited by Felipe Pedrell. Barcelona: Juan Pujol and Company, 1894.

Paetzold, Christopher. "Singing Beneath the Alhambra: The North African and Arabic Past and Present in Contemporary Andalusian Music.” Journal of Spanish Cultural Studies 10 (2009): 207-209. doi:10.1080/1463200902990711.

Palestrina. "Missa Papae Marcelli," Novellos Original $8^{\text {th }}$ edition, Edited by Otto Goldschmidt. London: Novello and Company, n.d.

Pope, Isabel. "Spanish Secular Vocal Music of the Sixteenth Century." Renaissance News 2 (1949): 1-5. doi:10.2307/2857475.

Ramos, Pilar. "Musical practice and idleness: a moral controversy in Renaissance Spain.” Acta Musicologica 81 (2009): 255-274. http://www.jstor.org/stable/23075161.

Ramsey, Shirley (performer). Music of the Spanish Renaissance. Naxos, 8550614, 1994, compact disc. Recorded in 1993.

Rasmussen, Anne. "The Arab World." In Worlds of Music: An Introduction to the Music of the World's Peoples, edited by, Jeff Todd Titon, 503. Belmont, CA: Schirmer Cengage Learning, 2009.

Robertson, Carol E., ed. Musical Repercussions of 1492: Encounters in Text and Performance. Washington D.C.: Smithsonian Institution Press, 1992. 
Sanlucar, Manolo and Corey Whitehead. "The Speculative Theories of Manolo Sanlucar: The Greek Origins of Flamenco Music." International Journal of the Humanities 7 (2011): 7-19.

Shannon, Jonathan H., "Performing al-Andalus, Remembering alAndalus: Mediterranean Soundings from Mashriq to Maghrib." Journal of American Folklore 120 (2007): 308-334. doi: $10.2307 / 20487557$.

Stevenson, Robert. Spanish Cathedral Music in the Golden Age. Los Angeles: University of California Press, 1961.

Titon, Jeff Todd, ed. Worlds of Music: An Introduction to the Music of the World's Peoples. $5^{\text {th }}$ ed. Belmont, CA: Schirmer Cengage Learning, 2009.

Yang, Sandra. "Strengthening the 'History' in 'Music History': An Argument for Broadening the Cross-disciplinary Base in Musicological Studies." College Music Symposium 49 (2009): 239-242. 